\title{
Total hemosit udang vaname (Litopenaeus vannamei) yang dipelihara pada salinitas 10 ppt dengan padat tebar berbeda
}

\section{Total Haemocytes of Pacific White Shrimp (Litopenaeus vannamei) cultured at salinity of $10 \mathrm{ppt}$ in various stocking density}

Dian Febriani ${ }^{\mathrm{a}}$, Eulis Marlina ${ }^{\mathrm{a}}$, dan Adni Oktaviana ${ }^{\mathrm{a} *}$

${ }^{a}$ Program Studi Budidaya Perairan, Jurusan Peternakan, Politeknik Negeri Lampung

adni_zein@polinela.ac.id

\begin{abstract}
Abstrak
Penelitian ini bertujuan untuk mengetahui total hemosit dan sintasan udang vaname (L. vannamei) yang dipelihara pada salinitas $10 \mathrm{ppt}$ dan dengan padat tebar yang berbeda. Penelitian ini terdiri dari tiga perlakuan dengan tiga ulangan. Udang vaname dipelihara pada salinitas $10 \mathrm{ppt}$ dengan padat tebar $150 \mathrm{ekor} / \mathrm{m}^{2}$ (A), $200 \mathrm{ekor} / \mathrm{m}^{2}(\mathrm{~B})$, dan $250 \mathrm{ekor} / \mathrm{m}^{2}$ (C). penelitian ini dilaksanakan selama lima minggu. Hasil yang diperoleh dari penelitian ini adalah udang vaname yang dipelihara pada salinitas $10 \mathrm{ppt}$ dengan padat tebar berbeda berpengaruh terhadap pertumbuhan. Namun tidak berpengaruh terhadap kelangsungan hidup dan juga total hemosit udang. Perlakuan yang menghasilkan pertumbuhan terbaik adalah padat tebar $150 \mathrm{ekor} / \mathrm{m}^{2}$.
\end{abstract}

Kata kunci: udang vaname, salinitas, Padat tebar, total hemosit, sintasan.

\begin{abstract}
This study aimed to determine total haemocytes and survival rate of pacific white shrimp cultured at $10 \mathrm{ppt}$ in various stocking density. This study consisted of three treatments with three replicates. The shrimp was cultured at salinity of $10 \mathrm{ppt}$ with different stocking densities: $150 \mathrm{shrimps} / \mathrm{m}^{2}$ (A), 200 shrimps $/ \mathrm{m}^{2}$ (B), and 250 shrimps $/ \mathrm{m}^{2}$ (C). The result showed that different stocking density affected significantly on the growth performance but gave no effect on the survival and the total of shrimp haemocytes. This study was conducted for five weeks. The best growth performance was seen in the treatment with stocking density of 150 shrimps $/ \mathrm{m}^{2}$.
\end{abstract}

Keywords: Pacific White Shrimp, Salinity, Stocking density, Total Haemocytes, Survival rate. 
Journal of Aquaculture Science

DOI: https://doi.org/10.31093/joas.v3i1.35

\section{PENDAHULUAN}

Udang vaname (Litopenaeus vannamei) merupakan salah satu komoditas yang sangat diminati di masyarakat. Udang vaname bersifat euryhaline atau dapat hidup pada rentang salinitas yang luas $(0,5-40$ ppt).

Budidaya udang vaname selama ini dilakukan di tambak atau keramba jaring apung (KJA). Dimana budidaya tersebut menggunakan media yang bersalinitas tinggi. Namun pada saat ini budidaya udang di tambak sedang mengalami fase penurunan, akibat seringnya terjadi serangan penyakit. Menurut data Shrimp Club Indonesia (SCI), produksi udang Indonesia pada tahun 2016 hanya sekitar 265.000 ton, menurun dari tahun 2014 sebesar 300.000 ton. Hal tersebut mempengaruhi produksi udang vaname di pasaran (Medistiara, 2017). Hal ini memberikan dampak yang signifikan terhadap produksi udang nasional. Oleh karena itu, diperlukan alternatif untuk meningkatkan produksi udang vaname. Salah satu alternatif tersebut adalah budidaya udang vaname di pekarangan dengan salinitas rendah.
Budidaya udang vaname di pekarangan mulai dilakukan sejak tahun 2012 (Anonim, 2016). Namun belum menggunakan salinitas rendah. Salah satu faktor keberhasilan budidaya udang vaname lain adalah padat tebar yang optimal. Padat tebar mempengaruhi pertumbuhan dan juga kesehatan udang vaname. Oleh karena itu, diperlukan informasi tentang status kesehatan dan juga sintasan udang vaname yang dibudidayakan pada salinitas 10 ppt dengan padat tebar berbeda.

Penelitian ini ingin melihat jumlah hemosit total dan sintasan udang vaname yang dibudidayakan dengan salinitas 10 ppt pada padat tebar berbeda.

\section{BAHAN DAN METODE}

\section{Persiapan hewan uji}

Penelitian ini dilaksanakan selama lima minggu di Laboratorium Budidaya Perikanan Politeknik Negeri Lampung. Hewan uji yang digunakan adalah udang vaname stadia post-larval (PL) 10 yang berasal dari hatchery komersil di Kalianda, Bandar Lampung. Sebelum digunakan benur dipelihara 
Journal of Aquaculture Science

DOI: https://doi.org/10.31093/joas.v3i1.35
April 2018 vol 3 (1): 1-8

Online pada http://joas.co.id terlebih dahulu diadaptasikan pada media salinitas 10 ppt. Salinitas air laut diturunkan secara perlahan setiap harinya hingga mendapat salinitas 10 ppt. Penurunan salinitas air laut dilakukan dengan menambahkan air tawar 5\% dari volume air laut dalam akuarium. Penambahan air tawar sebanyak $5 \%$ dari volume air laut dalam akuarium bertujuan untuk menurunkan salinitas air laut sebesar 2 ppt. Volume media pemeliharaan sebanyak 30 liter. Wadah yang digunakan berupa akuarium berukuran $50 \mathrm{~cm}$ x $40 \mathrm{~cm}$ x $30 \mathrm{~cm}$ sebanyak 9 buah yang telah didesinfeksi. Kemudian akuarium ditutup dengan plastik hitam untuk menghindari stress pada udang dan diberikan aerasi.

\section{Desain penelitian}

Penelitian ini terdiri dari tiga perlakuan dengan tiga ulangan dan menggunakan rancangan acak lengkap. Perlakuan yang diberikan yaitu perlakuan A (pemeliharaan udang vaname pada salinitas $10 \mathrm{ppt}$ dengan padat tebar $\left.150 \mathrm{ekor} / \mathrm{m}^{2}\right)$, perlakuan B (pemeliharaan udang vaname pada salinitas 10 ppt dengan padat tebar 200 ekor $\left./ \mathrm{m}^{2}\right)$, dan perlakuan $\mathrm{C}$ (pemeliharaan udang vaname pada salinitas $10 \mathrm{ppt}$ dengan padat tebar 250 ekor $/ \mathrm{m}^{2}$ ).

\section{Parameter yang diamati}

Parameter yang diamati antara lain average daily growth (ADG) (Nimrat et al,. 2011), sintasan udang vaname (Effendi, 2004), dan total hemosit (Sang et al., 2009) serta pengukuran kualitas air. Parameter kualitasa air yang diamati antara lain suhu, oksigen terlarut (DO), nilai $\mathrm{pH}$, dan amoniak.

\section{HASIL DAN PEMBAHASAN}

\section{Total hemosit (THC)}

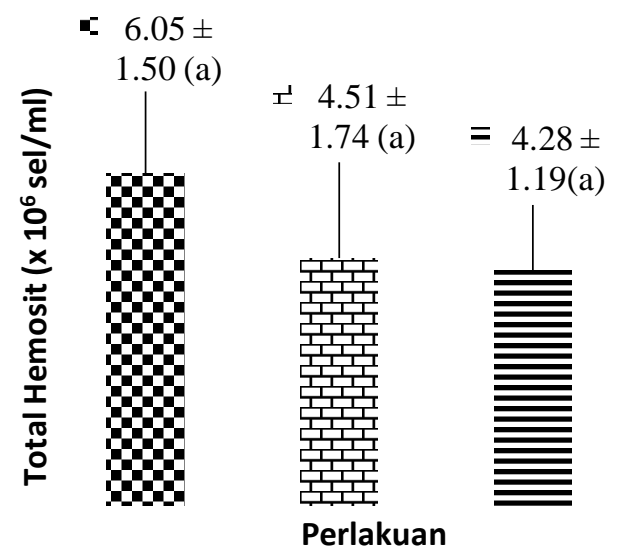

Gambar 1. Total hemosit (THC) selama 35 hari pemeliharaan pada salinitas 10 ppt dengan padat tebar berbeda. Data (mean \pm standar deviasi). Keterangan A: salinitas $10 \mathrm{ppt}$ dengan padat tebar 150 ekor/m²; B : salinitas 10 ppt dengan padat tebar 200 ekor $/ \mathrm{m}^{2}$; dan C : salinitas $10 \mathrm{ppt}$ dengan padat tebar 250 ekor $/ \mathrm{m}^{2}$. 
Journal of Aquaculture Science

DOI: https://doi.org/10.31093/joas.v3i1.35
April 2018 vol 3 (1): 1-8

Online pada http://joas.co.id
Total hemosit (THC) pada penelitian ini menunjukan hasil yang tidak berbeda secara signifikan antara ketiga perlakuan. Nilai THC yang diperoleh pada perlakuan secara berturut-turut yaitu A $\left(6,05 \times 10^{6} \quad \mathrm{sel} / \mathrm{ml} \quad \pm 1,50\right), \quad \mathrm{B}$ $\left(4.51 \times 10^{6} \mathrm{sel} / \mathrm{ml} \pm 1,74\right)$ kemudian $\mathrm{C}$ $\left(4,28 \times 10^{6} \mathrm{sel} / \mathrm{ml} \pm 1,19\right)$ (Gambar. $1)$.

Pemeliharaan udang vaname pada salinitas 10 ppt dengan padat tebar berbeda menunjukkan hasil yang baik. Hemosit merupakan sistem pertahanan selular pada udang vaname, yang bertanggung jawab terhadap fagositosis, nodulasi dan enkapsulasi (Sahoo et al., 2007). Jumlah hemosit yang tinggi menunjukkan tingkat kesehatan udang. Oktaviana, dkk (2014), menyatakan bahwa jumlah hemosit pada kontrol negatif udang vaname yang diberikan sinbiotik sebesar 3,93 X $10^{6} \mathrm{sel} / \mathrm{ml}$.

Penelitian ini menunjukan bahwa udang pada ketiga perlakuan dalam kondisi yang sehat. Dapat dilihat dari total hemosit yang diperoleh berkisar antara 4,28-6,05 x $10^{6} \mathrm{sel} / \mathrm{ml}$. Menurut Yeh et al.,
(2009), jumlah hemosit udang sehat dengan bobot 11-12 g/ekor berjumlah $1,80 \pm 9,28 \times 10^{7} \mathrm{sel} / \mathrm{ml}$. Dapat disimpulkan bahwa perlakuan yang diberikan tidak menyebabkan fisiologis terutama kesehatan udang terganggu.

\section{Sintasan (SR)}

SR atau tingkat kelangsungan hidup pada penelitian ini menunjukan hasil yang tidak berbeda secara signifikan antara ketiga perlakuan. Nilai SR yang diperoleh pada perlakuan secara berturut-turut yaitu B $(92,31 \% \pm 7,69)$, A $(81,48 \%$ $\pm 23,13)$ kemudian C $(70,83 \% \pm$ 7,22) (Gambar. 2).

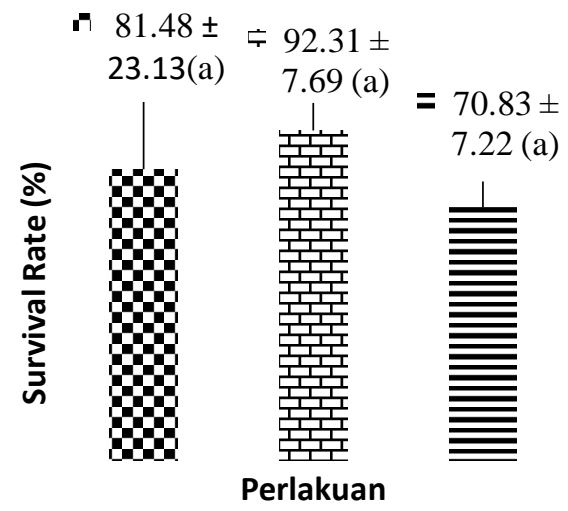

Gambar 2. Sintasan (SR) selama 35 hari pemeliharaan pada salinitas 10 ppt dengan padat tebar berbeda. Data (mean \pm standar deviasi). Keterangan A : salinitas $10 \mathrm{ppt}$ dengan padat tebar $150 \mathrm{ekor} / \mathrm{m}^{2}$; B : salinitas $10 \mathrm{ppt}$ dengan padat tebar 200 ekor $/ \mathrm{m}^{2}$; dan C : salinitas $10 \mathrm{ppt}$ dengan padat tebar 250 ekor $/ \mathrm{m}^{2}$. 
Journal of Aquaculture Science

DOI: https://doi.org/10.31093/joas.v3i1.35
April 2018 vol 3 (1): 1-8

Online pada http://joas.co.id
SR yang diperoleh pada penelitian ini menunjukkan bahwa udang vaname yang dipelihara pada salinitas 10 ppt dengan padat tebar berbeda tidak berbeda nyata. Hal ini sesuai dengan Supriyono, dkk (2006), yang menyatakan bahwa padat tebar berbeda tidak berpengaruh terhadap kelangsungan hidup udang vaname. Hal tersebut juga ditunjukan pada produksi tokolan udang windu (Djumadi, 2005).

\section{Average Daily Growth (ADG)}

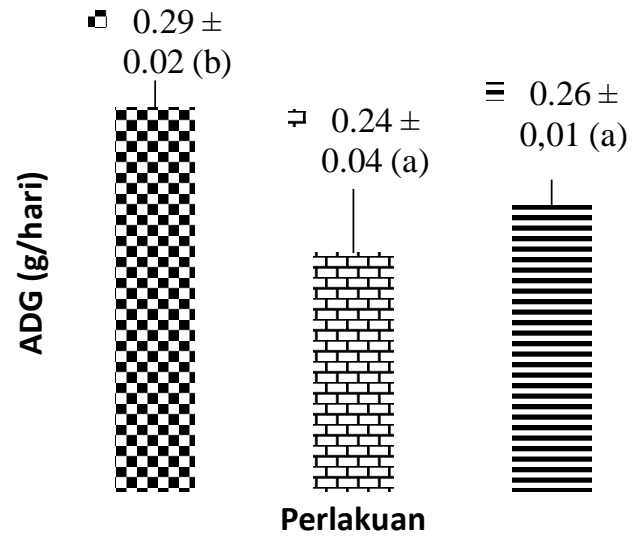

Gambar 3. Average Daily Growth (ADG) selama 35 hari pemeliharaan pada salinitas $10 \mathrm{ppt}$ dengan padat tebar berbeda. Data (mean \pm standar deviasi) dengan huruf berbeda menunjukan berbeda nyata $(\mathrm{p}<0,05)$ antar perlakuan. Keterangan A : salinitas $10 \mathrm{ppt}$ dengan padat tebar 150 ekor $/ \mathrm{m}^{2}$; $\mathrm{B}$ : salinitas $10 \mathrm{ppt}$ dengan padat tebar 200 ekor $/ \mathrm{m}^{2}$; dan C : salinitas $10 \mathrm{ppt}$ dengan padat tebar 250 ekor/m²
ADG pada penelitian ini menunjukan hasil yang berbeda secara signifikan antara perlakuan A dengan perlakuan B dan C. Nilai ADG yang diperoleh pada perlakuan secara berturut-turut yaitu A $(0,29$ $\mathrm{g} /$ hari $\pm 0,02), \mathrm{C}(0,26 \mathrm{~g} / \mathrm{hari} \pm 0,01)$ kemudian B $(0,24 \mathrm{~g} /$ hari $\pm 0,04)$ (Gambar. 3).

Rata-rata pertumbuhan harian (ADG) terbaik ditunjukkan pada perlakuan A. Hal ini menunjukkan bahwa padat tebar yang baik untuk budidaya udang vaname pada salinitas $10 \mathrm{ppt}$ adalah $150 \mathrm{ekor} / \mathrm{m}^{2}$. Pertumbuhan dipengaruhi oleh beberapa faktor. Faktor yang mempengaruhi pertumbuhan terbagi menjadi faktor internal dan eksternal. Faktor internal yang mempengaruhi pertumbuhan adalah genetik dan fisiologi misal tingkat kesehatan sedangkan faktor eksternal adalah pakan, padat tebar dan juga kualitas air (Watanabe, 1988).

Pertumbuhan udang vaname pada penelitian ini menunjukan hasil yang lebih baik dibandingkan dengan Gunarto dan Mansyur (2007). Dimana pertumbuhan udang vaname yang dipelihara selama 76 hari dengan pemupukan susulan dan 
dengan padat tebar berbeda hanya mencapai 20-21 g. Menurut Aziz (2010), pertumbuhan udang vaname pada salinitas rendah (0-10 ppt) lebih tinggi dibandingan pada salinitas 30 ppt. Hal ini disebabkan pada salinitas rendah terjadi perubahan tekanan osmotik yang mengakibatkan penyerapan air dari lingkungan ke dalam tubuh udang vaname. Sehingga bobot tubuh udang vaname menjadi bertambah dan tesktur dagingnya menjadi lebih lunak.

Hasil penelitian ini dapat dilihat bahwa pertumbuhan terbaik udang vaname dengan padat tebar berbeda pada salinitas $10 \mathrm{ppt}$ adalah $150 \mathrm{ekor} / \mathrm{m}^{2}$. Hal ini sesuai dengan penelitian Alkindy (2006), dimana pertumbuhan udang vaname terbaik didapat pada padat tebar $100-150$ ekor $/ \mathrm{m}^{2}$.

\section{KUALITAS AIR}

Kualitas air yang terukur selama lima minggu pemeliharaan udang vaname pada salinitas $10 \mathrm{ppt}$ dengan padat tebar berbeda tersaji pada tabel 1 di bawah ini.

Tabel 1. Data kualitas air selama penelitian

\begin{tabular}{lcccc}
\hline \multirow{2}{*}{ Parameter } & \multicolumn{3}{c}{ Perlakuan } & Referensi \\
\cline { 2 - 4 } & $\mathbf{A}$ & $\mathbf{B}$ & $\mathbf{C}$ & (WWF Indonesia, 2014) \\
\hline DO $(\mathrm{ppm})$ & $4-6$ & $4-6$ & $4-6$ & $>4$ \\
Suhu $\left({ }^{\circ} \mathrm{C}\right)$ & $28-30$ & $28-30$ & $28-30$ & $28-32$ \\
Salinitas $(\mathrm{ppt})$ & 10 & 10 & 10 & $15-25$ \\
$\mathrm{pH}$ & $7,8-8$ & $7,5-8$ & $7,6-8,1$ & $7,5-8$ \\
$\mathrm{NH}_{3}(\mathrm{ppm})$ & 0 & 0 & 0 & 0 \\
\hline
\end{tabular}

Kualitas air yang terukur

pada penelitian ini termasuk dalam kualitas air yang optimal bagi udang vaname. Namun dengan salinitas yang lebih rendah dibandingkan salinitas optimal hidup udang vaname. Salinitas berhubungan erat dengan tekanan osmotik dan ionik air. Perubahan salinitas menyebabkan perubahan tekanan osmotik, dimana semakin rendah salinitas maka semakin rendah pula tekanan osmotiknya (Vernberg dan Vernberg, 1972). Regulasi osmotik pada krustasea merupakan mekanisme penting untuk adaptasi lingkungan (Yudiati, dkk., 2009). Udang vaname bersifat euryhaline atau dapat hidup pada rentang salinitas yang luas. Udang vaname dapat hidup pada rentang salinitas 0 45 ppt.

\section{KESIMPULAN}


Journal of Aquaculture Science

DOI: https://doi.org/10.31093/joas.v3i1.35
April 2018 vol 3 (1): 1-8

Online pada http://joas.co.id
Kesimpulan yang diperoleh

dari kegiatan penelitian ini adalah total hemosit udang yang dibudidayakan pada salinitas $0 \mathrm{ppt}$ dengan padat tebar berbeda adalah 4,28-6,05 x $10^{6} \mathrm{sel} / \mathrm{ml}$. Sintasan udang yang dibudidayakan pada salinitas 0 ppt dengan padat tebar berbeda adalah 70,83-92,31\%.

\section{UCAPAN TERIMA KASIH}

Penelitian ini dibiayai oleh DIPA Politeknik Negeri Lampung. Benih udang yang digunakan berasal dari hatchery PT Biru Laut Khatulistiwa Lampung.

\section{DAFTAR PUSTAKA}

Alkindy, BL. 2006. Pembesaran Udang Vaname (Litopenaeus vannamei) dalam Bak Pemeliharaan dengan Padat Tebar Berbeda. [SKRIPSI]. Departemen Budidaya Perairan. Fakultas Perikanan dan Ilmu Kelautan. Institut Pertanian Bogor

Anonim. 2016. Model Budidaya Udang Skala Rumahan (CP Prima). http://www.trobos.com/detailberita/201 6/01/15/86/7004/-model-budidayaudang-skala-rumahan-cp-prima. Diakses 10 Juli 2017. 8.50 WIB

Aziz, R. 2010. Kinerja Pertumbuhan dan Tingkat Kelangsungan Hidup Udang Vaname (Litopenaeus vannamei) pada Salinitas 30 ppt 10 ppt 5 ppt dan 0 ppt. [SKRIPSI]. Departemen Budidaya Perairan. Fakultas Perikanan dan Ilmu Kelautan. Institut Pertanian Bogor

Briggs, M. Smith, FS. Phillips, M. 2004. Introductions and Movement of Penaeus vannamei and Penaeus stylirostris in Asia and the Pasific. Food and Agriculture Organization of
United Nations. RAP Publication 10:112

Cuzon, G. Lawrence, A. Gaxiola, G. Rosas, C. dan Guillaume, J. 2004. Nutrition of Litopenaeus vannamei Reared in Tanks or in Ponds. Aquaculture 235:513-551

Djumadi, R. 2005. Produksi Tokolan Udang Windu (Penaeus monodon Fabricus) dalam Hapa pada Tambak Intensif dengan Padat Tebar 250 ekor $/ \mathrm{m}^{2} 500$ ekor/m $\mathrm{m}^{2} 750$ ekor/m² dan 1000 ekor $/ \mathrm{m}^{2}$. [SKRIPSI]. Fakultas Perikanan dan Ilmu Kelautan. Institut PErtanian Bogor. Bogor

Effendi I. 2004. Pengantar Akuakultur. Depok: Penebar Swadaya

Gunarto dan Mansyur, A. 2007. Budidaya Udang Vanamei (Litopenaeus vannamei) di Tambak dengan Padat Tebar Berbeda Menggunakan Sistem Pemupukan Susulan. Jurnal Riset Akuakultur Volume 2 No. 1:167-176

Huisman EA. 1987. Principles of Fish Production. Netherland: Department of Fish Culture and Fisheries. Waganingen Agriculture University

KKP. 2016. Tahun Ini, KKP Targetkan Produksi Udang Capai 600 Ribu Ton. kkpnews.kkp.go.id. 8 Januari 2016

Lemire, J. Mailloux. R. Appanna, V. D. 2008. Zinc Toxicity Alters Mitochondrial Metabolism and Leads to Decreased ATP Production in Hepatocytes. Journal of Applied Toxicology 28: 175-182

Martines FS. 2007. The immune system of shrimp. Boletines Nicovita Alimentando tu Confianza. www.nicovita.com.pe

Medistiara, Y. 2017. Produksi Udang Turun Jadi 265.000 ton Tahun Lalu. https://finance.detik.com/beritaekonomi-bisnis/3433995/produksiudang-turun-jadi-265000-ton-tahunlalu. 10 Juli 2017. 8.31WIB

Nimrat, S. Boonthai, T. and Vuthiphandchai, V. 2011. Effects of Probiotic Forms, Compositions of and Mode of Probiotic Administration on Rearing of Pasific White Shrimp (Litopenaeus vannamei) Larvae and Postlarvae. Animal Feed Science and Technology 169: 244-258

Oktaviana, A. Widanarni dan Yuhana. M. 2014. The Use of Synbiotics to Prevent IMNV and Vibrio harveyi Co-Infection in Litopenaeus vannamei. Hayati Journal of Bioscience 21 (3): 127-134 
Journal of Aquaculture Science

DOI: https://doi.org/10.31093/joas.v3i1.35

Pyng Yeh S, Nan Chen Y, Hsieh SL, Cheng W, Liu CH. 2009. Immune Response of White Shrimp Litopenaeus vannamei after A Concurrent Infection with White Spot Syndrome Virus and Infectious Hypodermal and Hematopoietic Necrosis Virus. Fish and Shellfish Immunology 26: 582-588

Ramu K, Zakaria. 2000. Defence Mechanism in Crustacea. Infofish International 5:30-32

Sahoo PK, Pillai BR, Mohanty J, Kumari J, Mohanty S, Mishra BK. 2007. In vivo humoral and cellular reaction, and fate of injected bacteria Aeromonas hydrophila in freshwater prawn Macrobrachium rosenbergii. Fish and Shellfish Immunology 23:327340

Sang HM, Ky LT, Fotedar R. 2009. Dietary supplementation of mannan oligosaccharide improves the immune responses and survival of marron, Cherax tenuimanus (Smith, 1912) when challenged with different stressors. Fish and Shellfish Immunology 27:341-348

Setiawati, M. Azwar, N.R. Mokoginta, I. Affandi, R. 2007. Kebutuhan Mineral Seng (Zn) untuk Benih Ikan Gurame (Osphronemus gouramy, Lac). Jurnal Akuakultur Indonesia 6 (2): 161-169

Supriyono, E. Purwanto, E. dan Utomo, N. B. P. 2006. Produksi Tokolan Udang Vanamei (Litopenaeus vannamei) dalam Hapa dengan Padat Penebaran yang Berbeda. Jurnal Akuakultur Indonesia 5(1): 57-64

Vernberg, W.B., Vernberg, F.J., 1972. Environmental Physiology of Marine Animal. Springer-Verlag, New York

Watanabe, T., 1988. Fish Nutrition and Mariculture. Departement of Aquatic Bioscience. Tokyo University of Fisheries. JICA, p: 233

WWF Indonesia. 2014. BMP Budidaya Udang Vaname Tambak Semi Intensif dengan IPAL. Seri Panduan Perikanan Skala Kecil Edisi 1. Jakarta: WWFIndonesia

Yeh, SP. Chen, YN. Hsieh, SL. Cheng, W. Liu, CH. 2009. Immune Response of White Shrimp Litopenaeus vannamei after Concurrent Infection with White Spot Syndrome Virus and Infectious Hypodermal and Hematopoietic
April 2018 vol 3 (1): 1-8

Online pada http://joas.co.id

Necrosis Virus. Fish and Sellfish Immunologies 26: 582-558

Yudiati, E. Sedjati, S. Enggar, I dan Hasibuan, I. 2009. Dampak Pemaparan Logam Berat Kadmiun pada Salinitas yang Berbeda Terhadap Mortalitas dan Kerusakan Jaringan Insang Juvenil Udang Vaname (Litopenaeus vannamei). Indonesian Journal of Marine Science 14 (4): 29-35

Zonneveld N, Huisman EA, Boon JH. 1991. Prinsip-Prinsip Budidaya Ikan. Jakarta: Gramedia Pustaka Utama 